\title{
Lab Networks in Engineering Education: A Proposed Structure for Organizing Information
}

\author{
https://doi.org/10.3991/ijoe.v16i05.11891 \\ Giovanni Romagnoli ${ }^{(凶)}$, Giovanni Esposito, Antonio Rizzi, \\ Francesco Zammori \\ University of Parma, Parma, Italy \\ giovanni.romagnoli@unipr.it \\ Massimo Bertolini \\ University of Modena and Reggio Emilia, Modena, Italy \\ Dieter Uckelmann \\ Hochschule für Technik Stuttgart, Stuttgart, Germany
}

\begin{abstract}
Experimentation plays an essential role in engineering education, allowing to balance theoretical proofs and emphasis on physical intuition. Laboratories can fulfil several goals at once, but they also involve high costs, mostly due to equipment, space, and human resources for operating and maintaining them. Remote-access labs have been proposed as a feasible alternative: developed since the early 2000 s by an ever-increasing research community, they are real or virtual labs accessible at distance through a computer network. Recently, alternative bibliometric taxonomies and classifications of current networked remote-access labs have been proposed. Yet, none of these works proposes a comprehensive structure to collect and organize the information, especially from a technical perspective, aiming at the definition of the state of the art and future outlooks of provided solutions. In the present work, we fill this gap extending previous works by enlarging their set of criteria towards a general multi-layer model for networked remote-access labs. We performed a systematic review of relevant literature to retrieve useful information and to design the data collection and classification structure, which is finally validated performing a mini-Delphi method.
\end{abstract}

Keywords - Lab-based education; lab network initiatives; remote lab; classification; internet of things.

\section{$1 \quad$ Introduction}

Experimentation and laboratories play a main role in technical education, since they allow to achieve pedagogical objectives, such as learning to manipulate the physical environment and understanding its constraints, by applying theory to practice [1]. According to Antsaklis et al. [2], lab experimentation fulfils the following goals: 
- Comparing theoretical results with real world results, thus validating the theory and justifying analytic concepts.

- Introducing real world factors, which are usually disregarded in analytical solutions, e.g. saturation, noise, uncertainty.

- Widening students' focus on secondary design issues, e.g. hardware selection and implementation, and economic considerations.

- Providing students with the opportunity to experience professional techniques and practice, e.g. maintaining engineering notebooks, writing reports, brainstorming, team building and problem solving.

Especially in Science, Technology, Engineering and Mathematics (STEM) education, laboratories are used to combine formal mathematical learning with practical experience. Indeed, they make it possible to develop simulative models (based on theoretical principles) and to compare them with real equipment and devices: this balance between analytical solutions and experimental evidences is considered a major challenge in control education [3]. Although it is highly recommended to provide a learning path that includes learning through an 'actual experience', hands-on labs, which are the traditional solution, involve high costs relating to equipment, space, and maintenance staff [4]. For this reason, the interest of the research community in 'non-traditional labs' has been growing steadily since 2008 [5]. Although in Section 2 we provide a brief discussion on the vocabulary used in the literature on labs and experimentations, we anticipate that, in this work, the term 'non-traditional labs' is used to underline the difference from the traditional hand-on ones [6].

Many authors have analysed the evolution of non-traditional labs to provide insights of their continuously-improving learning outcomes, which are nowadays often proved to be comparable to those of traditional labs [6] - [8]. Other authors even claim that non-traditional labs can broaden the learning outcomes, since they provide insight into experimentation aspects otherwise indiscernible (e.g. heat transfer, electromagnetism), and they allow to interact with equipment parts otherwise covered or protected, e.g. robot mechanisms [9], [10]. Gravier et al. [11] identified additional advantages of nontraditional labs, such as: Laboratory safety, Availability, Accessibility, Experimentation observability.

Potkonjak et al. [12] focused on the possibility of conducting the experiments by several roles and involvement levels (i.e. multiple access, flexibility and change in the system configuration), and on equipment's preservation. However, the literature also provides some disadvantages of non-traditional labs, as virtualisation requires a highcomputing capacity and may negatively impact on the users' attitude towards experiments. Relatively to the last issue, virtual experiments could be performed with little care, as in a video-game experience, and this may create a lack of a seriousness to approach the experiments [12]. These limitations often suggest providing also an 'actual experience', combined with the non-traditional one.

Since the early 2000s, the number of studies on non-traditional labs has grown amazingly [5]. Zappatore et al. [13] state that, in this research area, two common threads exist: (i) The rising pedagogical interest in lab-based education. (ii) Technology advancements in lab connection and networking. 
The former thread has been widely discussed in technical literature, and some of the main studies are listed below. Gustavsson et al. [7] dealt with the need for laboratory work in engineering and showed how remote labs can provide this opportunity. Giemza et al. [14] focused on a specific pedagogical approach which is supported by virtual labs. The study by de Jong et al. [15] focused on the teachers' needs when using a Learning Management System (LMS), and the requirements that it must fulfil to offer a fruitful didactical and learning experience.

The latter thread has also been addressed in the literature. Just to provide some examples, Richteret al. [16] defined a high-level architecture to establish a repository of labs that can be easily integrated into LMSs. Halimi et al. [17] provided a standardized layered structure for remote-lab integration, and Harward et al. [18] focused on software architecture and middleware requirements for the same goal. However, it is opinion of the authors that there still is a lack of wide-ranging studies that consider technical information on existing lab network initiatives (LNIs), alongside with more general information (e.g. related to didactic and organisational aspects of LNIs). In fact, a major issue of this literature thread is the fact that many studies limit the discussion to specific features of singular LNIs and, consequently, they often miss to provide a comprehensive and holistic vision, which is a sound base for implementing new non-traditional LNIs [4]. A first attempt to describe experimentation environments from a technical point of view is the one proposed by Dormido Bencomo [19], who defined the main characteristics of remote labs and four classification criteria for virtual labs. In his work, the author identifies five requirements of a remote lab: (i) Simple installation and use

(ii) Access through the internet, (iii) No charge for the user, (iv) Interactivity and realism (v) Total availability.

Also, the classification of virtual labs relates to four criteria: (i) The location of the mathematical calculation engine, (ii) The nature of the simulation kernel (iii) The design capacities (iv) The degree of simulation interactivity.

This work has been the ground to define what non-traditional labs are, and to set the general rules for their development. However, this work is almost 20 years old, and both technology and society have tremendously evolved since then. Just to provide an example, the concept of 'laboratory as a service' (LaaS) has emerged in the last decade, proposing the user-as-a-consumer vision and subjecting him/her to subscription fees [20]; this concept is not included in the classification scheme by Dromido Bencomo, because it was impossible to foresee it in 2004.

A more recent attempt in this direction has been made by Potkonjak et al. [12]. In this study, the authors propose a semi-qualitative review of relevant lab-network initiatives (LNI) and they identify four criteria to assess the quality of virtual labs, starting from the following main requirement: 'operating a virtual laboratory for a student must feel like they are working with real authentic devices in a real authentic space' [12]. Specifically, the four criteria are: (i) The user interface has to replicate the corresponding real device (ii) The behaviour of the virtual system has to be equivalent to the behaviour of the physical system (iii) The visualisation must allow students to feel like they are performing the experiment in the real environment (iv) The communication and collaboration environment should be provided as a 3D laboratory. 
These criteria will be discussed more in-depth in Section 3. Here, we just want to stress the differences between the approach by Dormido Bencomo [19] and the one by Potkonjak et al. [12]. As it is shown in Table 1, where we try to match the four criteria proposed in the two studies, the approach of Dormido Bencomo [19] seems to be more focused on the 'location' and on the 'features' of the software module behind the virtual system, whereas the one by Potkonjak et al. [12] is more oriented on its 'performance on the user side'. Perhaps this equivalence is rather stiff (e.g. where the 'nature of the simulation kernel' is matched with 'visualisation'), nonetheless it should be of help for a preliminary understanding of the main criteria that are used to class non-traditional labs, and of the trend of related researches, since twelve years passed between the two works.

Although the above-mentioned approaches are very useful, we believe that both Dormido Bencomo [19] and Potkonjak et al. [12] addressed the problem from a qualitative point of view, without a real technical focus, especially concerning lab networking development of both remote and virtual labs. This issue can be quite important for those who may want to pursue the goal, reported in several studies, of framing a network of networks-of-labs, which may become a need, more than an alternative, for non-traditional labs [21]. In the present study, we extend the previously cited works providing a set of assessment criteria based on a broad multi-layer model for a network of labs, and we propose a comprehensive structure to collect and organize general and, most of all, technical information on LNIs. Thus, the aim of this work is to provide the scientific community with a tool that can be used to depict from a, mostly, technical point of view the state of the art of LNIs. It is opinion of the authors that such a structure can provide great value to organizations that shall build a new LNI and, more in general, it can improve the knowledge of the scientific community on technologies and resources available within different LNIs.

Table 1. Difference among the models for virtual systems (VS) from Dormido Bencomo [19] and Potkonjak et al. [12]

\begin{tabular}{|l|l|l|}
\hline Authors & Dormido Bencomo [19] & Potkonjak et al. [12] \\
\hline Focus on & Location and features & Performance on the user side \\
\hline \multirow{5}{*}{ Models' Criteria } & $\begin{array}{l}\text { Location of the mathematical calculation } \\
\text { engine }\end{array}$ & [No match] \\
\cline { 2 - 3 } & Nature of the simulation kernel & Visualisation \\
\cline { 2 - 3 } & \begin{tabular}{l} 
Design capacities \\
\cline { 2 - 3 }
\end{tabular} & $\begin{array}{l}\text { Communication and collaboration envi- } \\
\text { ronment }\end{array}$ \\
\cline { 2 - 3 } & Degree of simulation interactivity & Behaviour of the virtual system \\
\cline { 2 - 3 } & [No Match] & User interface \\
\cline { 2 - 3 } & Dormido Bencomo [19] & Potkonjak et al. [12] \\
\hline
\end{tabular}

The remainder of the paper is organized as follows. In Section 2 we propose an overview of exiting literature on remote-access labs and LNIs. In Section 3 we focus on a recent attempt of classifying information on LNIs and we illustrate its merit and limitations. In Section 4 we propose a structure to organize relevant information on LNIs, and we provide an example on how this information must be filled in. Finally, we provide discussion and conclusions in Section 5. 


\section{A Brief Analysis of Existing Literature}

The debate on non-traditional labs was first introduced by the National Science Foundation and the Control Systems Society at a workshop on 'New Directions in Control Engineering Education', held at the University of Illinois at Urbana-Champaign twenty years ago [3]. After the study of Antsaklis et al. [2], the research community has produced a lot of literature on this topic. Just to have an idea, Heradio et al. [5] counted more than 1,000 works published in the three-years period spanning from 2012 to 2014. In the early 2000s, the scientific debate focused, mainly, on the following topics: (i) The necessity to classify and characterize the laboratories (ii) The definition of a common vocabulary (iii) The further developments needed to ensure the use of non-traditional laboratories in STEM education [22].

Regarding the first issue, related to the need of a classification of the labs, the first attempt to define a proper taxonomy belongs to Dormido Bencomo [19], who proposed a two-dimensional classification that uses the 'access to the resource' and the 'nature of the resource' as classification criteria. Specifically, he defined four cases by combining local or remote access to the resource, with its real or simulated nature:

- Local access-real resource

- Local access-simulated resource

- Remote access-real resource

- Remote access-simulated resource

A further attempt is the one by Zutin et al. [23], who discussed 'the creation of a common framework to describe laboratories according to the semantic web technology'. They identified four cases by considering the utilization of equipment and devices rather than the access to the resources. Pfeiffer and Uckelmann [24] further extended the possible scenarios by introducing the concept of network (see Figure 1), which has become a trendy topic in recent literature. In the remainder of the paper we will stick to the classification of labs presented by Zutin et al. [23].

Regarding the second point, related to the lexicon setting, a common vocabulary of non-traditional laboratories is still missing. Although progress has been made and the term 'online lab' is generally accepted as the standard [25], [26], other terms such as 'virtual and remote labs' [3], [27], and 'non-traditional labs' [6] are frequently used in relevant literature, to identify both remote and virtual labs. Since we believe that the 'access method' is more appropriate than the 'type of performed experimentation' to distinguishing between different labs, as in the classification provided by Zutin et al. [23], we will use the term remote-access laboratories to identify any remote-experimentation environments, either virtual or real. Regarding the third topic, recent attempts have contributed significantly to the selection of worthwhile literature, and to its mapping, with the aim of identifying specific research topics [5], [13]. Beyond proposing a normalized dataset of bibliographic references in lab-based education, Zappatore et al. [13] proposed a structured data processing framework for producing it. Their work is very useful, not only for the comprehensive dataset that it has made available, but also because it provides the research community with an approach to define which are the 
relevant features in lab-based education. Heradio et al. [5] have instead performed a science mapping of the lab-based education research community, by means of co-word and co-citation analysis. Through this approach, they provided the readers with useful information concerning the linkages between research themes and their evolution in a twenty-two-year timespan, trying to address the future outlooks for lab-based education and research. In particular, the authors indicated the following emerging needs: (i) An efficient combination of virtual and remote labs (ii) The development of increasingly collaborative learning environments (iii) The assessment of the pedagogical effectiveness of remote-access learning concepts.

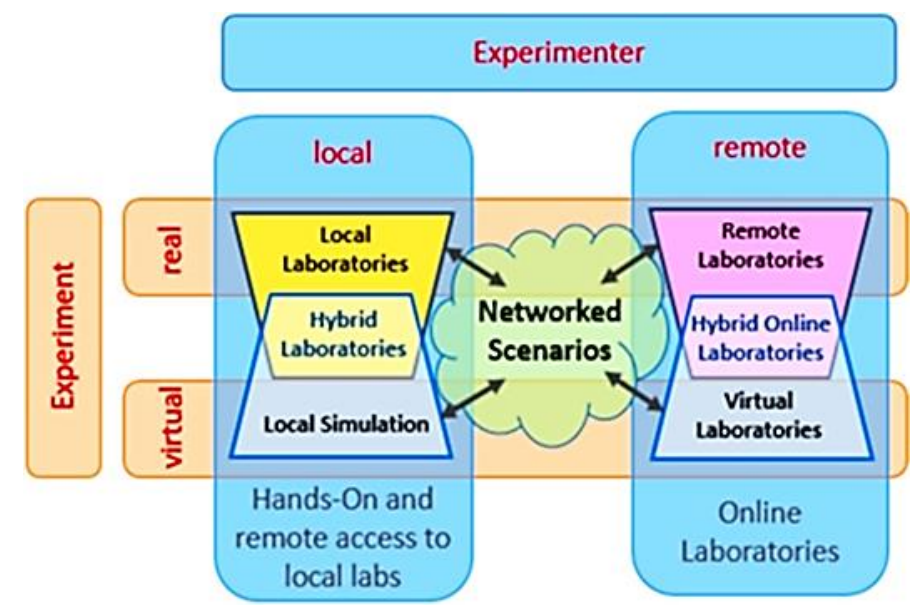

Fig. 1. Classification of labs according to Zutin et al. [23] and extended by Pfeiffer and Uckelmann [24]

A further interesting contribution to the research on remote-access labs comes from the experience of research projects on laboratories and LNIs, such as the aforementioned works by Harward et al. [18], Richter et al. [16], and Halimi et al. [17], relating to the iLab Shared Architecture project (http://ilab.mit.edu/wiki), the Library of Labs LiLa project (http://library-of-labs.org), and the Go-Lab project (https://www.golabz.eu/), respectively. In this context, i.e. projects that both promote and are the object of the research, we can also cite:

- The WebLab-Deusto project (https://weblab.deusto.es/), which has provided an interesting contribution to research on remote-access labs, with an holistic approach to the development and implementation of labs and LNIs [21], [28].

- The Virtual Labs (www.vlab.co.in/), an initiative of the Ministry of Human Resource Development (MHRD), Government of India under the aegis of National Mission on Education through Information and Communication Technology (NMEICT), involving a consortium of twelve Indian institutes, which provides distance web- enabled experiments in ICT-based education [29].

- The University Network of Interactive Labs (UNILabs, https://unilabs.dia.uned.es/), a network of several Spanish and South-American universities that share their 
laboratory resources for education purposes [30], in a web 2.0 environment, i.e. the "dynamic web", whose goal is to allow users to read, write and collaborate on the topics they are addressing [31].

- The OpenScience Laboratory (https://learn5.open.ac.uk/course/view.php?id=2), of the Open University in the UK, which has been very used in experiment-based research activities [32], [33].

- The Virtual Instruments System In Reality project (VISIR+, http://www2.isep.ipp.pt/visir/), started by Blekinge Institute of Technology (BTH) in Sweden together with National Instruments in USA and Axiom EduTech in Sweden, developed hands-on, virtual, and real-remote laboratories in Electrical and Electronics Engineering. The aim is to promote new teaching and learning methodologies for engineering education [7] shared by a network of academic partners that nowadays also includes eleven institutions from Spanish, Portuguese and Latin American areas [34].

- The Platform Integration of Laboratories based on the Architecture of visiR (PILAR, http://www.ieec.uned.es/pilar-project/index.html?lng=en), funded by the EU program Erasmus+, with the aim to interconnect all VISIR systems in a superstructure, providing a well-defined set of open practices, available through the Internet as a set of services [35].

Heradio, de la Torre and Dormido [3] stated that, although the research projects on laboratories and LNIs have provided an outstanding contribution to the research community, there are few reviews that analyse and classify them. Starting from these premises, they provided a survey of nine research projects and of the related forty remoteaccess labs active in 2016; all labs were fully characterized in terms of access type and experimentation availability. Conversely, Potkonjak et al. [12] followed a different approach to perform a qualitative analysis, with a particular focus on robotic virtual labs, of an interesting set of remote-access labs that were selected among twenty research projects funded by national and international frameworks (e.g. LiLa and Go-Lab), learning platforms provided by single Universities (e.g. Virtual laboratory of Process Control) [36], and commercial products (e.g. Robologix by Logic Design Inc - LDI Canada).

By analysing all the twenty-nine projects of these two reviews, excluding those ones focusing on software development for robotics' virtual labs (as can be deduced from the work of and Potkonjak et al. [12]), it is possible to identify a sub-set of fifteen suitable research projects, eight of which, more than the $50 \%$ of the sample, relate to LNIs or network of networks. This result highlights the key role played by public-funded research projects, in supporting the development of remote-access laboratories. Considering the gap in analysing and classifying the project experiences, as pointed out by [3], we argue that it is useful to perform further analysis to introduce suitable indicators to describe the context and the technical aspects of the LNIs. 


\section{$3 \quad$ The Model Proposed by Potkonjak et al. [12]}

In their classification, Potkonjak et al. [12] make use of four evaluation criteria, that we report below in a slightly modified version, which is more in line with our own classification (original text from [12] is reported in quotes).

- C1 - Realistic User Interface: 'The user interfaces, for each piece of equipment, must be identical to the corresponding real devices.' Meeting this requirement is very important, especially for the labs used for operators' training. It mainly concerns programming, and it is relatively simple to be achieved. Possible criticalities could arise in case of device copyright to replicate.

- C2 - Realistic Systems Replication: 'The behavior of the virtual system (e.g. state and control variables) must be equivalent to the system behavior in the physical paradigm.' This requirement concerns the kinematics and the dynamics of the virtualised equipment. To accurately replicate the behaviour of the physical system, a mathematical model is generally needed. Its formulation depends on the teaching field of the system and it can be made using either general purpose or dedicated simulative models.

- C3 - Realistic Graphical Representation: 'Visualization must be provided that makes students feel like they are looking at a real authentic thing.' Meeting this criterion is fundamental to experimentation labs reproducing complex systems (e.g. manufacturing cells, logistic system, etc.) whose elements move synchronously in space, can interact, collide and interfere with each other. In case of static and/or 2D systems, achieving this requirement is less important.

- C4 - Support for Communication and Collaboration: 'A 3D laboratory space must be created which allows for communication and collaboration among students and with the lab supervisor (or expert in the field). ' Probably, this is the most innovative criterion introduced by the authors. To meet this requirement, developers should create a virtual world to support not only the planning and the implementation of the experimentations, but also the overall learning environment, to which the experimentation activities belong to. In addition to the experts and/or the developers, also basic user (e.g. students) should be allowed to improve the learning process, by operating in a Virtual Interactive 3D Environments (VIDE). Students, as well as supervisors, may also choose an avatar in a VIDE [37], in perfect analogy with a serious game.

Potkonjak et al. applied these criteria to map the labs of the twenty initiatives onto requirements' meeting, and they found that only the Virtual laboratory at Stevens Institute of Technology [25], [38] fully complies to all four criteria. It is also worth noting that, since only nine, out of twenty, were robotics' labs, the authors made it clear that the four criteria can be used also for labs that do not relate to the robotics' field, and that their aim was to propose a general model suitable for all web-based learning services. In details, the model entails: (i) A lower level of learning for system operator (ii) A higher level of education towards the design and development of applications 
(iii) The use of platforms for inquiry learning, towards openness and interoperability through traditional LMS and new 3D virtual world platforms ([12]).

The purpose of designing a model in such a way is twofold, as it allows: (i) Dealing with new technologies and services, which have not yet been really considered in education, e.g. equipment for immersive environments and virtual worlds for experiments design and implementation. (ii) Highlighting the weaker aspects of the existing virtual and remote laboratories, i.e. criteria $\mathrm{C} 2$ and $\mathrm{C} 4$ related to dynamic modelling and virtual spaces reproduction and, more in general, a higher level of flexibility to create new objects to be included in the experiment.

These two aspects are particularly relevant if the experiment relies on virtual and remote labs developed in a mixed-reality environment.

As noted in the introduction of the present study, albeit suitable, the model by Potkonjak et al. has some limitations: (i) The lack of a structured general contextualization of the labs and lab-networks, i.e. labs' scope is disregarded

(ii) The lack of a common reference-framework addressing the selection of the criteria, i.e. the classification of labs and lab-networks is more qualitative than quantitative

(iii) The lack of a set of criteria for framing a network of networks of labs.

Owing to these issues, the goal of the present study is to expand the four criteria of the model by Potkonjak et al., using a suitable layered reference-framework for remoteaccess labs. The proposed structure is detailed in Section 4.

\section{The Proposed Framework to Collect and Organize Informa- tion on LNIs}

In this section we provide the structure to collect material on LNIs and to organize them into a display-board. Also, to prove the applicability of our structure, and to provide the reader with a practical example of how many fields can be filled in when information is collected on a specific LNI, we introduce a descriptive case study composed of three LNIs, which is reported in Appendix A. These examples show that, although most of the LNIs will not fill every field of the database, the database itself is complete, in the opinion of the authors, as it allows to gather all information that is relevant to describe the specific solution.

Concerning the structure, we have first defined three dimensions to cluster the suitable information. They are:

- 'General Information' - This dimension is related to the organizational aspects of the project. Indeed, it organizes data relative to the stakeholders of the lab (network), to the project's duration and activities. It also reports all the sources where related information can be found.

- 'Context Information' - This dimension is mostly related to the didactic and thematic aspects of the labs, as it deals with general labs' characteristics and availability. It also details the type of experiments (that can be performed) and the kind of users that can log on the lab. 
- 'Technical Information' - This dimension specifically addressed the technical details of the implemented solutions. We note that, in this dimension, the technical point of view might also be directed on 'non-technical' aspects of the LNI, such as didactic (e.g. learning analytics and learner record store) or organisational aspects (functionalities of the client layer and access levels).

Concerning the last point, we are aware that, in case of a network of labs, collecting technical details for them all and synthesizing them in a single data collection framework is a hard and time-consuming task. Still, since this information can be very valuable, we propose to proceed as follows. When answering to each question, the analyst should consider the best performing lab with respect to the specific question. Should the number of labs be too big to be handled, labs could be clustered in groups with similar characteristics and technologies. Thus, the best performing lab of each cluster could be more easily taken as a reference. This process will then generate a pseudo-lab which synthesizes the best characteristics of the whole LNI. This approach is aligned with our aim to describe the state-of-the-art in terms of devices, techniques and services [39]. We are aware that this approach cannot entail information about learning objectives for which the labs were designed, as those learning objectives can differ among the labs and cannot be reported at our pseudo-lab level. Nevertheless, our intent is more focused on the technical aspects and on the lab architecture, rather than on teaching and learning objectives.

Next, to detail the three dimensions, we defined a set of Key Attributes (KAs), whose nature and number depend on the dimension itself. The KAs are information that categorize the laboratory, and they are described through a series of items, structured in a multi-level hierarchical way, that provide low-level information (relative to the implemented solution), either of quantitative or qualitative nature. Both KAs and items belonging to the three dimensions were selected through an accurate analysis of relevant literature on remote-access labs and were validated by the cross-functional team of the DigiLab4U project, comprehending seventeen subject matter experts from five German and Italian higher education institutions (for the list of institutions, see www.digilab4u.com). Specifically, the validation process was performed by means of a miniDelphi strategy as the one suggested in the work by Neaga and Henshow [40]. The full list of KAs and their relative items is shown in Table 2, where the structure is applied to a descriptive case study, and in Table 3, where the exact meaning of each item is reported.

The first dimension 'General Information' $(G)$ is detailed through ten KAs related either to the organizational aspects of the project or to the sources of information related to the project. Note that, being a descriptive dimension, $\mathrm{G}$ is directly described through KAs, and it does not need lower-level items.

The second dimension 'Context Information' (C) comprises seven KAs related to the network (if the project involves a network), to the type of experimentation and to the access to the labs. Concerning lab typology, the detailed information is gathered by means of four first-level items, namely: 'Virtual', 'Remote', 'Hybrid', and 'Gaming'. Note that the first three items correspond to the 'remote-experiment' part of the lab classification proposed by Zutin et al. [23], but there is not a specific item concerning 
the 'Networked' scenarios suggested by Pfeiffer and Uckelmann [24]. This is because we believe that the network type and its architecture are the core of a remote-access labs; hence we dedicated to the network description a specific KA, within the 'Context Information' dimension. Also, we opted to consider 'Gaming' as a specific item, because it both relates to virtual worlds supporting specific laboratories [12], as well as to Game-Based Learning and to Serious Games. Since gaming-based learning scenarios often make use of computer-based gaming, it is our opinion that they are a real mix of real/virtual and local/remote solutions [41]. Furthermore, in previous classifications, serious games have never been considered. However, the use of this learning-game tool is growing considerably, thus we decided to consider this item separately, because of its novelty and specificity.

Finally, the third-dimension deals with 'Technical Information' (T) and it addresses the technical solutions implemented by the lab-network. The KAs in this dimension are six, and they are described through thirty-eight items. Four KAs, out of the six of this dimension, directly refer to the four-layer reference-framework (for remote-access labs) introduced by Zapata Rivera and Larrondo Petrie [26], of which, a readapted version is shown in Figure 2.

1. The upper layer is the 'Client Layer' that provides the user an interface to requestlbook a practical session and to interact with remote lab experiments by communicating with the learning environment, or directly with the remote lab server. This layer coincides with the KA 'Client', which comprises six first-level items about the user and the access to the lab-network. The second-level items describe the possible roles of the users.

2. The second layer is the 'Learning Environment Layer', which exists when labs are embedded in an LMS. If so, performed activities can be evaluated as part of an exam or can be used to define a full pedagogic scenario and to assess learning analytics. The corresponding KA is the 'Learning Platform' and it collects three first-level items on the LMS (e.g. Moodle, edX and so on). The second-level items describe its functionalities.

3. The third layer is the 'RemoteLab Server Layer', which gives access to a remote laboratory through three resources: (i) the Access Manager, for validating the identity and authorization rights; (ii) the Scheduler, for the management of the user appointments and validation of the specific experiment, and (iii) the Resource Module, which implements the searching service over the indexed list of resources, using the metadata associated with each resource. The corresponding KA is the 'Remote Lab Server' and it consists of nine first-level items concerning the access to the experimentation, e.g. the Access Manager and the Lab Scheduler, and the experimentation typology, which consists of four second-level items properly related to the storage of the result, e.g. 'batch', 'sensor', 'interactive experiment', and 'repository'.

4. The fourth and last layer is the 'Physical Laboratory Layer', which implements a centralized Administrator Module responsible for the communications with the RemoteLab Server Layer and for the management of experimentation and devices. It also performs administrative activities (e.g. update new resources, report changes of schedules, etc.) and activates alerts. The corresponding KA is the 'Physical / Virtual 
lab' whose first-level items allows describing the software and the devices for the experimentation; the latter is described by means of four second-level items. In particular, we specify the difference between the second-level items 'smart sensors' and 'smart devices', to make clear that smart devices are able, self-sufficiently, to process data and to make them available online.

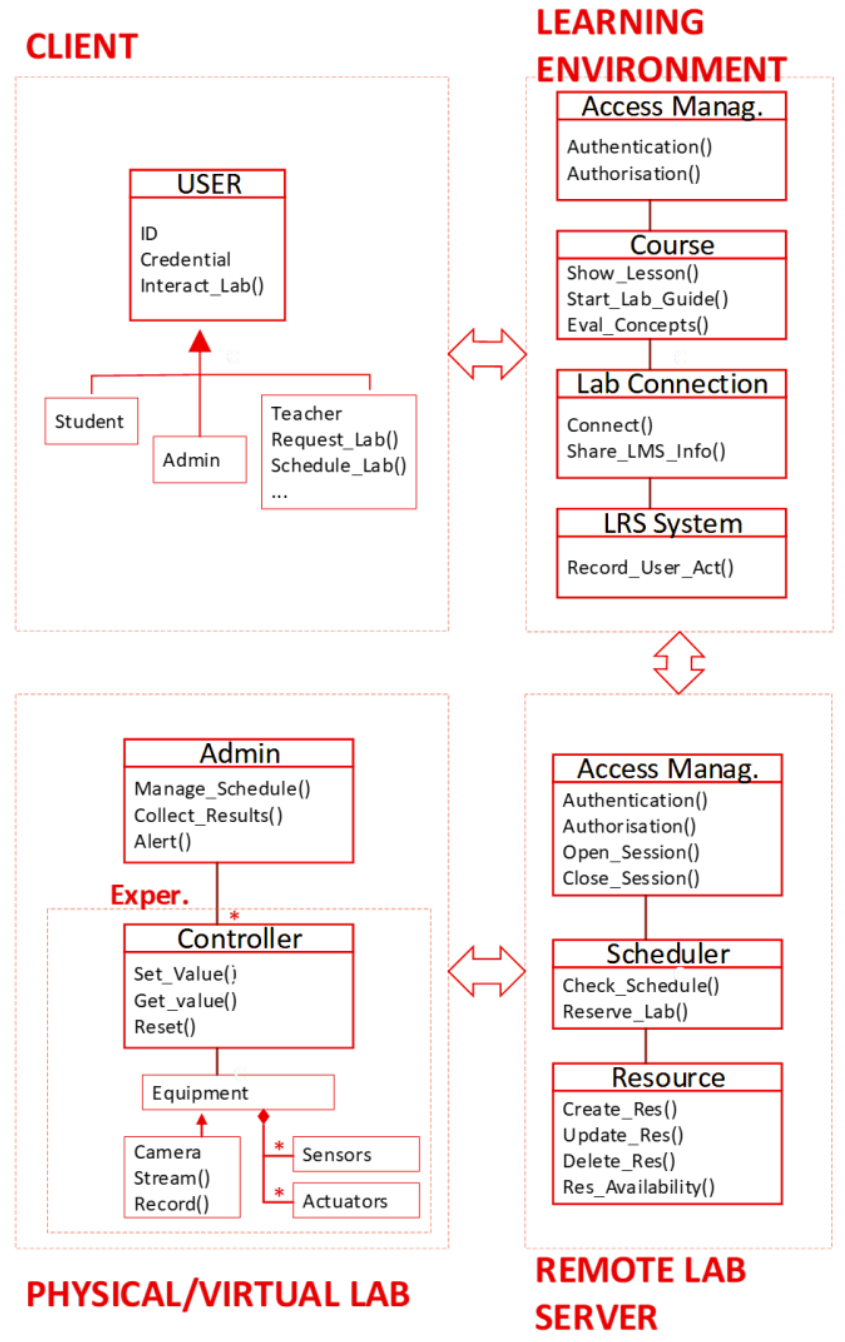

Fig. 2. The four-layer reference-framework readapted from Zapata Rivera and Larrondo Petrie

[26] used to identify the items of the dimension 'Technical Information'

It is worth noting the very technical characterization of the proposed structure, as, just the $28 \%$ of the items are of descriptive and qualitative nature, whereas the remaining $72 \%$ relate to technical features. Furthermore, the structure is deliberately very 
detailed, and maybe even characterized by an abundance of items. In our opinion, in fact, it should be considered as a checklist to guide the analyst in considering all the relevant issues when he or she classifies the existing remote-access lab, without missing important features. Finding a value for each item of the display-board would be the optimum but, to properly describe a laboratory, there is no need to fill in all its fields, as the amount of information depends on the typology of the lab and on the performed experimentation. In addition, we opted for a very detailed structure because, in this way, it can be used as a guideline also for designers developing novel and innovative remoteaccess labs. In summary, a very detailed structure has a twofold aim: (i) Supporting the provider of new remote-access labs in designing it (ii) Creating a common standard, in order to make the provided solution more visible to the research community.

The structure that we propose, provided with the explanation of each field is provided in Table 2. In the heading of the tables, D are the dimensions and KA are the key attributes.

For the sake of clarity, a part of the 'Technical Information' dimension is also described below. The first two KAs provide general information on the architecture of the lab: they are 'Number of layers of the lab architecture', and 'Full list of layer names'. The other four KAs correspond to the layers of the reference-framework for remoteaccess labs provided by Zapata Rivera and Larrondo Petrie [26]: 'Client', 'Learning Platform', 'Remote Lab Server' and 'Physical / Virtual (experiment)'. The items of the latter KA are:

1. The single-level information about the design software, used to develop the virtual labs.

2. The double-level information about the physical equipment and devices installed in the lab, namely:

a) Need of human actions (i.e., activities carried on by lab's staff) to perform the experiment.

b) List of devices and equipment used to operate and/or to automate the lab.

c) List of the devices used to transmit information, and classification of their nature (i.e. smart devices or smart sensors).

As a further example, the hierarchical structure of the 'Physical / Virtual' KA is shown in the cellular chart of Figure 3. As it can be seen, this KA belongs to the third dimension and it is described by means of two first-level items, highlighted in dark orange. Also, in case of Physical labs, additional information is collected by means of four second-level items, namely: 'Fully automated', 'Sensors, actuator, and controller', 'Smart Devices', and 'Smart Sensors'. 
Table 2. Fields of the structure to collect information and meaning of each item / key attribute. Please note that only the last level items must be quantified with a value. For the sake of comprehensions, KA and first level items that do not need to be quantified are highlighted with the symbol [-]

\begin{tabular}{|c|c|c|c|c|}
\hline D & KA & ID & Item & Go-Lab solution \\
\hline \multirow{10}{*}{ ש } & 1 & 1 & Project full name & $\begin{array}{l}\text { The name of the project and/or of the } \\
\text { main remote lab (hands-on laboratories } \\
\text { are not considered) }\end{array}$ \\
\hline & 2 & 2 & Coordinating organization & $\begin{array}{l}\text { Name of the main/lead/coordinating or- } \\
\text { ganization of the project }\end{array}$ \\
\hline & 3 & 3 & Partners of the project & $\begin{array}{l}\text { Other organizations directly involved in } \\
\text { the project, providing significant contri- } \\
\text { butions }\end{array}$ \\
\hline & 4 & 4 & Other organizations/institutions & $\begin{array}{l}\text { Other organizations providing non-sig- } \\
\text { nificant contribution (e.g. users, patron- } \\
\text { age, etc.) }\end{array}$ \\
\hline & 5 & 5 & Sponsor / funding organization & Main funding organization / body \\
\hline & 6 & 6 & Related papers (doi 1) & $\begin{array}{l}\text { IDs of papers describing or related to the } \\
\text { project (linked with a reference data } \\
\text { base) }\end{array}$ \\
\hline & 7 & 7 & Project starting year & First year of the project \\
\hline & 8 & 8 & Project finishing year & Last year of the project, if concluded \\
\hline & 9 & 9 & Active & Currently available / working \\
\hline & 10 & 10 & Abstract of the project & $\begin{array}{l}\text { A brief description of the project (in- } \\
\text { serted as an internal link to another ta- } \\
\text { ble) }\end{array}$ \\
\hline \multirow{8}{*}{ 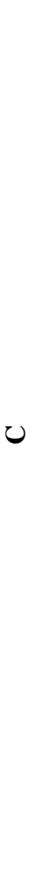 } & 11 & 11 & Network of labs & $\begin{array}{l}\text { Is it a labs-network (i.e., more physical } \\
\text { and virtual labs are connected through- } \\
\text { out the web) or is it a single lab? }\end{array}$ \\
\hline & 12 & 12 & If networked: how many labs? & $\begin{array}{l}\text { If so, how many labs are part of the net- } \\
\text { work? }\end{array}$ \\
\hline & 13 & 13 & Research / teaching fields & $\begin{array}{l}\text { List of the general fields/topics of the lab } \\
\text { (e.g. Engineering, Physics, Chemistry, } \\
\text { Biology, STEM etc.) }\end{array}$ \\
\hline & 14 & 14 & Users & $\begin{array}{l}\text { User for whom the lab has been de- } \\
\text { signed, i.e., P - Primary school }(<14 y) ; \mathrm{H} \\
\text { - high school (14 - 18); U - University } \\
(19+) ; \mathrm{R} \text { - researchers; C - companies; O } \\
\text { - others }\end{array}$ \\
\hline & 15 & 15 & Publicly available outside project partners & $\begin{array}{l}\text { State if external users not belonging to } \\
\text { the project's consortium can freely ac- } \\
\text { cess to the lab }\end{array}$ \\
\hline & 16 & 16 & $\begin{array}{l}\text { Experimentations in TE (\#TOTAL: \#re- } \\
\text { mote) }\end{array}$ & $\begin{array}{l}\text { Description of the specific kind of exper- } \\
\text { iment/simulation that can be performed } \\
\text { (e.g. design of electronic circuits, design } \\
\text { of robot cells, hydraulics systems, logis- } \\
\text { tics simulations, etc.) }\end{array}$ \\
\hline & \multirow[b]{2}{*}{17} & 17 & Types of laboratories (and \# per types) & $\begin{array}{l}\text { Type of lab, as defined in Zapata Rivera } \\
\text { and Larrondo Petrie [26] }\end{array}$ \\
\hline & & 17.1 & virtual (\#) & $\begin{array}{l}\text { Remote Access - Virtual Resources i.e., } \\
\text { A simulation environment accessible } \\
\text { through the web }\end{array}$ \\
\hline
\end{tabular}




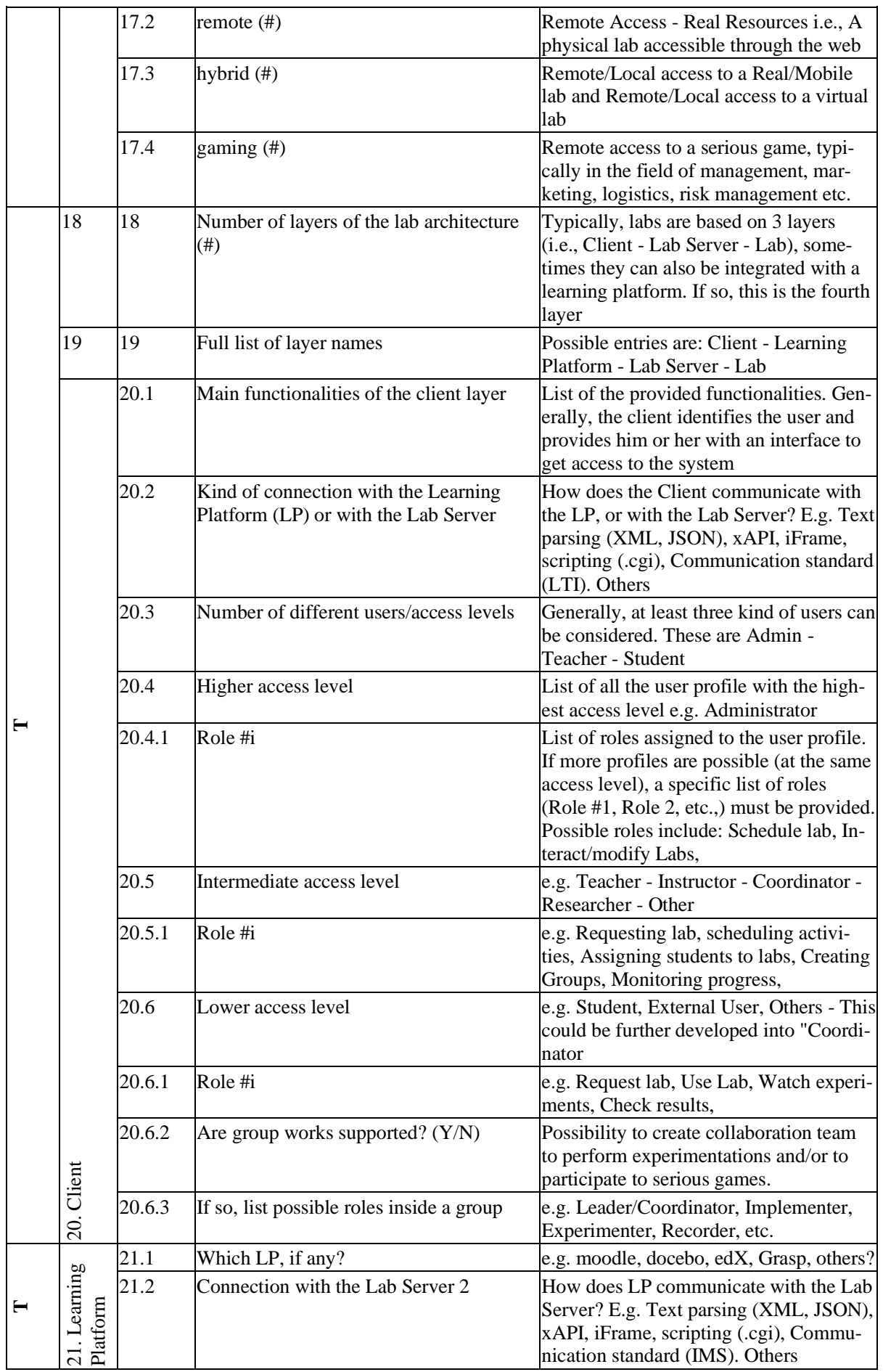




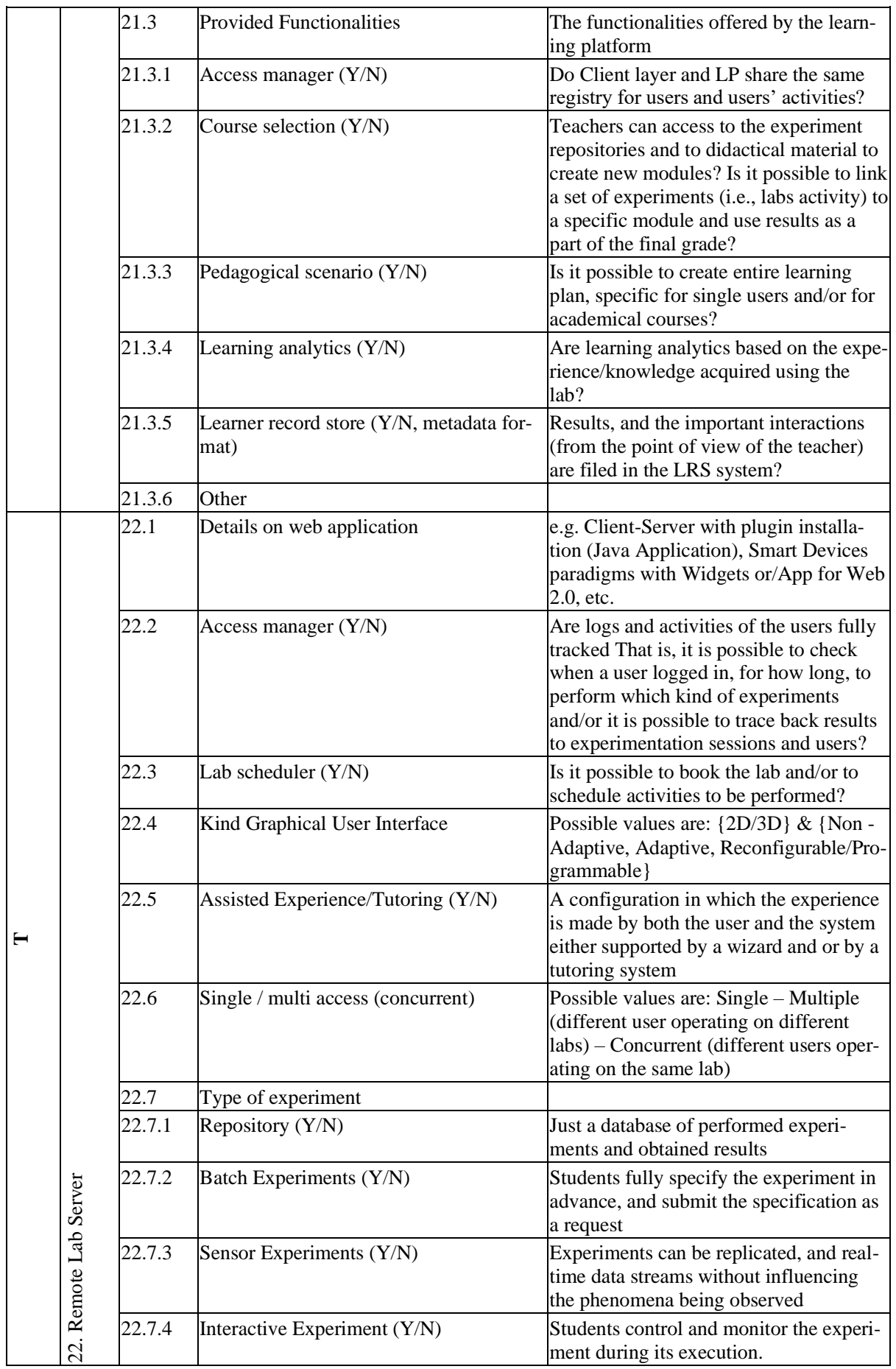




\begin{tabular}{|c|c|c|c|c|}
\hline & & 22.8 & Haptics (Y/N) & $\begin{array}{l}\text { Sensitive devices able to actuate real } \\
\text { equipment or to interact with virtual real- } \\
\text { ity models by returning feedback infor- } \\
\text { mation from the reaction force to the ac- } \\
\text { tion performed by the user }\end{array}$ \\
\hline & & 22.9 & Gamification (Y/N) & $\begin{array}{l}\text { The application of game principles into } \\
\text { non- game contexts in order to improve } \\
\text { user engagement, learning, evaluation }\end{array}$ \\
\hline \multirow{6}{*}{ E } & \multirow{6}{*}{ 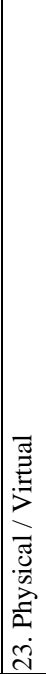 } & 23.1 & If virtual, which Design Software & $\begin{array}{l}\text { e.g. MATLAB, Simulink, ANSYS, } \\
\text { Arena, others }\end{array}$ \\
\hline & & 23.2 & If physical: & \\
\hline & & 23.2 .1 & Fully automated (Y/N) & $\begin{array}{l}\text { Possible values are: Low (human inter- } \\
\text { vention is needed during the experimen- } \\
\text { tation session), High (human interven- } \\
\text { tion is needed only for set-up activities), } \\
\text { Full (humans are never needed) }\end{array}$ \\
\hline & & 23.2 .2 & $\begin{array}{l}\text { Sensors, Actuator, and Controller: de- } \\
\text { scription }\end{array}$ & $\begin{array}{l}\text { List of the devices and equipment used } \\
\text { to operate the lab }\end{array}$ \\
\hline & & 23.2 .3 & Smart devices $(\mathrm{Y} / \mathrm{N})$ & $\begin{array}{l}\text { Devices endowed with some onboard in- } \\
\text { telligence (i.e., sensors and actuator, } \\
\text { identity and kind, memory and status } \\
\text { tracking, communication capabilities, } \\
\text { reasoning and learning) capable to com- } \\
\text { municate with other devices, sensor, and } \\
\text { items [42] }\end{array}$ \\
\hline & & 23.2 .4 & Smart sensors $(\mathrm{Y} / \mathrm{N})$ & $\begin{array}{l}\text { Sensors capable to elaborate and trans- } \\
\text { mit their state just to the control unit (in- } \\
\text { dustrial internet of things) [43] }\end{array}$ \\
\hline
\end{tabular}

${ }^{1}$ Used among others, for retrieving the information filling the database

${ }^{2}$ Although useful, this information is difficult to find. This field can be considered as optional

As we mentioned before, Table 3 (in Appendix A) reports an application of the structure to three different LNIs, also referred to as projects or 'ecosystems', namely GoLab (Global Online Science Labs), LiLa (Library of Labs) and WebLab-Deusto. GoLab (https://www.golabz.eu/) was a project co-funded by the European Commission ( $7^{\text {th }}$ Framework Programme, Grant agreement No 317601) which has developed the Go-Lab Ecosystem, a complex of services to share and create labs (i.e. the Go-Lab Sharing and Authoring Platform), which targets science teachers from primary and secondary schools and aims to help them enriching their teaching practices with innovative teaching approaches and supportive technical tools. LiLa (http://library-of-labs.org), co-funded by the eContentplus programme of the European Commission, is an initiative of eight universities and three enterprises, for the access and exchange of virtual and remote laboratories, including services like a scheduling and tutoring system, as well as connection to library resources and an environment for online collaboration. WebLab-Deusto (https://weblab.deusto.es/), started on early 2000s by testing different settings of a Computer Programmable Logic Devices through the internet, is an initiative of the University of Deusto aiming to increase experiential learning by means of remote and virtual laboratories, freely accessible through the Internet via an Open Source license software. 


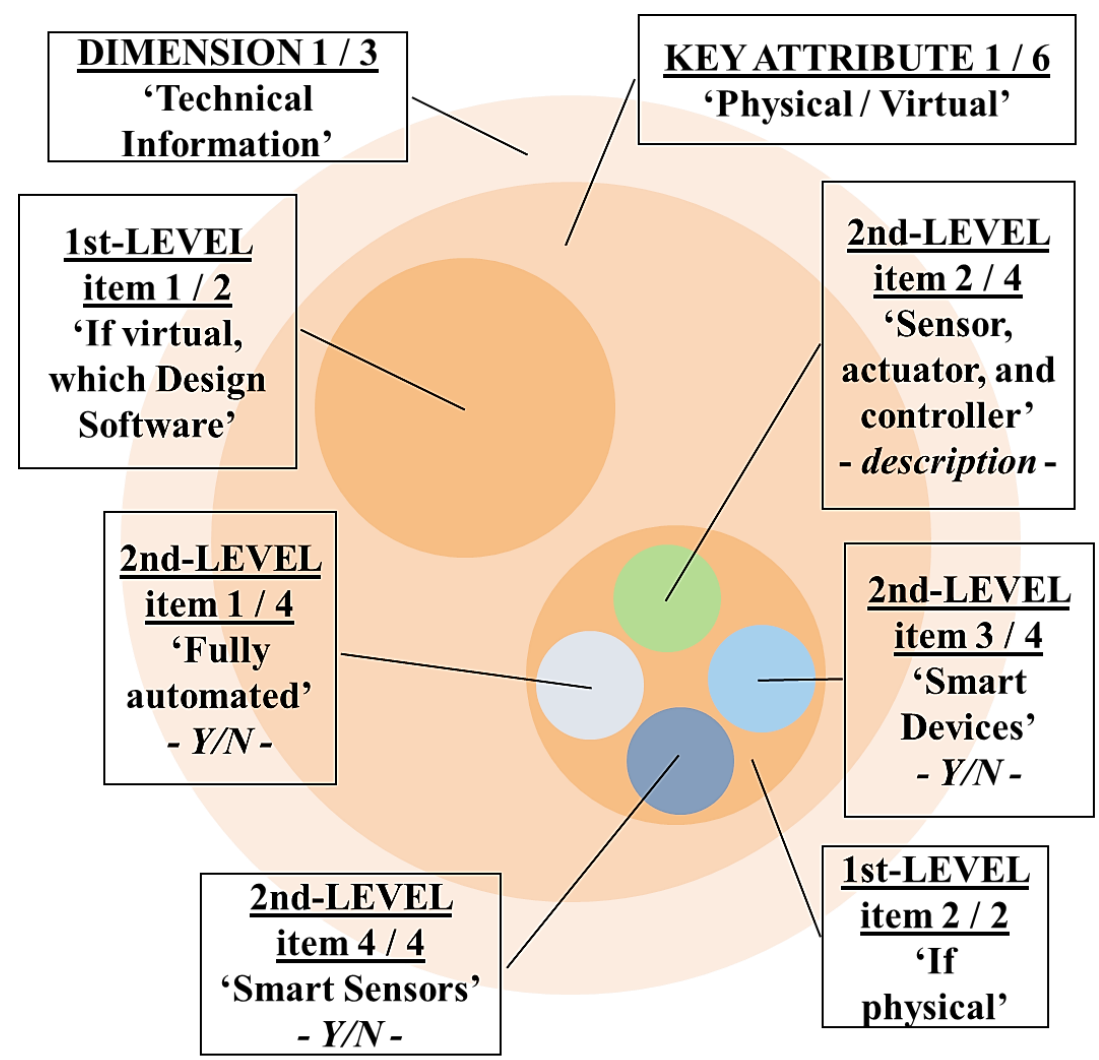

Fig. 3. "Cellular chart" of the structure to collect information for a single a single KA - i.e. Physical / Virtual (experiment) - belonging to the dimension 'Technical Information', and its two-level items

We selected these projects, which significantly differs from each other, because they are well-established learning environments that propose a great number of different laboratories. The information needed to fill Table 3 were collected as follows:

- We retrieved information on existing labs and previous initiatives, by reading the relevant literature on the topic. This literature was obtained by querying databases of peer-reviewed literature (e.g. Scopus), and freely accessible web search engine (i.e. Google Scholar). By analysing this literature, we identified suitable labs and networks

- We visited the website of the specific lab/network, as well as the website of the related project initiatives.

- We retrieved information by reading relevant literature on the specific subject.

- In case of missing data, we directly contacted the lab provider or the authors of relevant papers.

- We asked the lab provider to update or amend the information related to its lab, if possible. 
Concerning the fourth point of the bullet list, we explicitly noted above that we did not fill each display-board in all its fields. This is because our aim was to propose a data collecting framework and not to perform the analysis of the existing lab-networks, which will be the topic of future works. So, the results of Table 3 must be considered only as a demonstration example of the methodology, which is why the display board was not filled with data which were not readily available, or which would have required a direct use of the laboratories. Still, we note that the missing data average of the three examples is $30 \%$, a fact that confirms how, although somehow redundant, data included in the structure are quite easy to be found.

\section{$5 \quad$ Discussion and Conclusions}

Nowadays, providing laboratory experiences for students in STEM education is extremely important, both in terms of teaching and training reasons. Experimentations, in fact, allow explaining analytical concepts in practice. Moreover, they allow educating pupils in operational methodologies that will otherwise be learned just once they enter the labour market. Since traditional hands-on labs involve high costs (relating to equipment, space, and maintenance staff), and they require full-time personnel devoted to limited tasks, the interest of the scientific community in remote-access labs is continuously growing. Although researches have been originated for cost-savings reasons, a definite answer concerning the actual savings of remote-access labs is still missing, as they generate high costs in the development and in the maintenance phase (e.g. highcomputing devices, software development, reliable equipment and so on).

However, what emerges from the literature is that remote-access labs provide learning outcomes that are comparable to traditional hands-on labs, and they may provide further benefits widely validated by the research community. Despite researchers have produced a huge amount of literature on the topic, there is a gap between the literature proposed to solve specific problems for an individual remote-access lab or network, and the literature proposed to analyse the labs-network from an integrated and comprehensive point of view. This is noteworthy, because the information that can be obtained from past experiences can be useful to address new projects and design new remoteaccess labs and networks. With the aim of supporting both researchers analysing remote-access labs and practitioners who want to develop a new solution, in the present study we have provided a general pattern to retrieve the suitable information on labs and networks, by defining how to collect information and organize data in a suitable structure. Specifically, we have defined which information are required to fulfil the definition of the state-of-the-art in the remote-access lab-based education, and to support practitioners in the development of their own solution. We have distinguished between three information dimensions: the 'General Information' and the 'Context Information', which define the lab/network 'Identity Card', and the 'Technical Information', which sounds like the laboratory 'Specification sheet'. In particular, we believe that 'Technical Information' constitutes the real novelty of the paper, since previous studies have never provided technical information on the proposed solutions in a structured and comprehensive way. The proposed data collecting structure has also been reported in a 
practical display-board, where all relevant information of three different LNIs, namely Go-Lab, LiLa, and WebLab-Deusto, were filled in. To conclude, we note that such structure could be used to collect and organise information on existing LNIs (as well as past ones), with the aim of depicting the state-of-the-art on this topic. Also, the very same structure could be useful as a guideline for new projects and application of LNIs, as it promotes a technical approach to a wide set of LNIs, without disregarding organisational and didactical aspects. Indeed, the authors of these paper are already working on those topics for future research.

\section{Acknowledgement}

This research was funded by the German Federal Ministry of Education and Research BMBF, grant numbers 16DHB2112 (HFT Stuttgart) and 16DHB2116 (University of Parma) and was developed within forty-two-month project Digilab4U (https://digilab4u.com/).

\section{$7 \quad$ References}

[1] L. D. Feisel and A. J. Rosa, "The role of the laboratory in undergraduate engineering education,” J. Eng. Educ., vol. 94, no. 1, pp. 121-130, 2005. https://doi.org/10.1002/j.21689830.2005.tb00833.x

[2] P. Antsaklis, T. Basar, R. DeCarlo, N. H. McClamroch, M. Spong, and S. Yurkovich, "Report on the NSF/CSS workshop on new directions in control engineering education," IEEE Control Syst. Mag., vol. 19, no. 5, pp. 53-58, 1999. https://doi.org/10.1109/mcs.1999.793 $\underline{442}$

[3] R. Heradio, L. de la Torre, and S. Dormido, "Virtual and remote labs in control education: A survey," Annu. Rev. Control, vol. 42, pp. 1-10, 2016. https://doi.org/10.1016/j.arcont rol.2016.08.001

[4] L. Gomes and S. Bogosyan, "Current trends in remote laboratories," IEEE Trans. Ind. Electron., vol. 56, no. 12, pp. 4744-4756, 2009. https://doi.org/10.1109/tie.2009.2033293

[5] R. Heradio, L. De La Torre, D. Galan, F. J. Cabrerizo, E. Herrera-Viedma, and S. Dormido, "Virtual and remote labs in education: A bibliometric analysis," Comput. Educ., vol. 98, pp. 14-38, 2016. https://doi.org/10.1016/j.compedu.2016.03.010

[6] J. R. Brinson, "Learning outcome achievement in non-traditional (virtual and remote) versus traditional (hands-on) laboratories: A review of the empirical research," Comput. Educ., vol. 87, pp. 218-237, 2015. https://doi.org/10.1016/j.compedu.2015.07.003

[7] I. Gustavsson et al., "On objectives of instructional laboratories, individual assessment, and use of collaborative remote laboratories," IEEE Trans. Learn. Technol., vol. 2, no. 4, pp. 263-274, 2009. https://doi.org/10.1109/tlt.2009.42

[8] N. Kostaras, M. Xenos, and A. N. Skodras, "Evaluating usability in a distance digital systems laboratory class," IEEE Trans. Educ., vol. 54, no. 2, pp. 308-313, 2011. https://doi. org/10.1109/te.2010.2054096

[9] J. L. Chiu, C. J. Dejaegher, and J. Chao, "The effects of augmented virtual science laboratories on middle school students' understanding of gas properties," Comput. Educ., vol. 85, pp. 59-73, 2015. https://doi.org/10.1016/j.compedu.2015.02.007 
[10] D. Gillet, T. De Jong, S. Sotirou, and C. Salzmann, "Personalised learning spaces and federated online labs for STEM Education at School," IEEE Glob. Eng. Educ.Conf.EDU CON, pp. 769-773, 2013. https://doi.org/10.1109/educon.2013.6530194

[11] C. Gravier, J. Fayolle, B. Bayard, M. Ates, and J. Lardon, "State of the art about remote laboratories paradigms - foundations of ongoing mutations," Int. J. Online Eng., vol. 1, no. 1, pp. 1-9, 2008.

[12] V. Potkonjak et al., "Virtual laboratories for education in science, technology, and engineering: A review," Comput. Educ., vol. 95, pp. 309-327, 2016. https://doi.org/10.1016/ j.compedu.2016.02.002

[13] M. Zappatore, A. Longo, and M. A. Bochicchio, "The bibliographic reference collection GRC2014 for the Online Laboratory Research community," Proc. 2015 12th Int. Conf. Remote Eng. Virtual Instrumentation, REV 2015, no. February, pp. 24-31, 2015. https://doi. org/10.1109/rev.2015.7087258

[14] A. Giemza et al., "Learning by creating and exchanging objects: The SCY experience," Br. J. Educ. Technol., vol. 41, no. 6, pp. 909-921, 2010. https://doi.org/10.1111/j.1467-8535. 2010.01121.x

[15] T. de Jong, S. Sotiriou, and D. Gillet, "Innovations in STEM education: The Go-Lab federation of online labs," Smart Learn. Environ., vol. 1, no. 1, pp. 1-16, 2014. https://doi.org/ 10.1186/s40561-014-0003-6

[16] T. Richter, Y. Tetour, and D. Boehringer, "Library of Labs - A European project on the dissemination of remote experiments and virtual laboratories," Proc. - 2011 IEEE Int. Multimedia, ISM 2011, pp. 543-548, 2011. https://doi.org/10.1109/ism.2011.96

[17] W. Halimi, C. Salzmann, D. Gillet, and H. Saliah-Hassane, "Standardization Layers for Remote Laboratories as Services and Open Educational Resources," pp. 874-884, 2017. https://doi.org/10.1007/978-3-319-64352-6 81

[18] V. J. Harward et al., "The iLab shared architecture: A web services infrastructure to build communities of internet accessible laboratories," Proc. IEEE, vol. 96, no. 6, pp. 931-950, 2008. https://doi.org/10.1109/jproc.2008.921607

[19] S. Dormido Bencomo, "Control learning: present and future," Annu. Rev. Control, vol. 28, no. 1, pp. 115-136, Jan. 2004. https://doi.org/10.1016/j.arcontrol.2003.12.002

[20] M. Tawfik et al., "Laboratory as a service (LaaS): A novel paradigm for developing and implementing modular remote laboratories,” Int. J. Online Eng., vol. 10, no. 4, pp. 13-21, 2014. https://doi.org/10.3991/ijoe.v10i4.3654

[21] J. Irurzun and F. Gazzola, "Adding New Features to New and Existing Remote Experiments Through Their Integration in WebLab-Deusto," vol. 7, no. 2, pp. 33-39, 2011. https://doi.org/10.3991/ijoe.v7iS2.1774

[22] J. Ma and J. V. Nickerson, "Hands-on, simulated, and remote laboratories," ACM Comput. Surv., vol. 38, no. 3, pp. 7-es, 2006. https://doi.org/10.1145/1132960.1132961

[23] D. G. Zutin, M. E. Auer, C. Maier, and M. Niederstätter, "Lab2go - A repository to locate educational online laboratories," 2010 IEEE Educ. Eng. Conf. EDUCON 2010, pp. 17411746, 2010. https://doi.org/10.1109/educon.2010.5492412

[24] A. Pfeiffer and D. Uckelmann, "Open Digital Lab for You - Laboratory based training scenarios in education, research and qualification," 2019 IEEE $5^{\text {th }}$ Experimental International Conference (exp. At'19) 2019, pp. 36-41. https://doi.org/10.1109/expat.2019.8876560

[25] E. S. S. Aziz, S. K. Esche, and C. Chassapis, "Content-rich interactive online laboratory systems," Comput. Appl. Eng. Educ., vol. 17, no. 1, pp. 61-79, 2009. https://doi.org/10. 1002/cae.20210 
[26] L. F. Zapata Rivera and M. M. Larrondo Petrie, "Models of Collaborative Remote Laboratories and Integration with Learning Environments," Int. J. Online Eng., vol. 12, no. 09, p. 14, Sep. 2016. https://doi.org/10.3991/ijoe.v12i09.6129

[27] X. Chen, G. Song, and Y. Zhang, "Virtual and Remote Laboratory Development: A Review," in Earth and Space 2010, 2010, vol. 41096, no. July 2015, pp. 3843-3852. https:// doi.org/10.1061/41096(366)368

[28] J. García-Zubía, D. López-de-Ipiña, P. Orduña, and U. Hernández-Jayo, "Experience with weblab-deusto," in 2006 IEEE International Symposium on Industrial Electronics, 2006, vol. 4, pp. 3190-3195. https://doi.org/10.1109/isie.2006.296127

[29] K. M. Moudgalya, "Introducing National Mission on Education through ICT." 2010. [Online] Available: http://www.spoken-tutorial.org/NMEICT-Intro. [Accesses September 2019]

[30] J. Sáenz, J. Chacón, L. De La Torre, A. Visioli, and S. Dormido, "Open and Low-Cost Virtual and Remote Labs on Control Engineering,” IEEE Access, vol. 3, pp. 805-814, 2015. https://doi.org/10.1109/access.2015.2442613

[31] F. Hussain, "E-Learning 3.0= E-Learning 2.0+ Web 3.0?" in International Association for Development of the Information Society, 2012, pp. 11-18.

[32] E. Villasclaras-Fernandez, M. Sharples, S. Kelley, and E. Scanlon, "nQuire for the OpenScience Lab: Supporting Communities of Inquiry Learning," vol. 8095, 2013, pp. 585-588. https://doi.org/10.1007/978-3-642-40814-4_64

[33] M. M. Waldrop, "Education online: The virtual lab," Nature, vol. 499, no. 7458, pp. 268270, 2013. https://doi.org/10.1038/499268a

[34] M. Tawfik et al., "VISIR: Experiences and Challenges," Int. J. Online Eng., vol. 8, no. 1, Feb. 2012. http://dx.doi.org/10.3991/ijoe.v8i1.1879

[35] F. Garcia-Loro et al., "PILAR: a Federation of VISIR Remote Laboratory Systems for Educational Open Activities," in 2018 IEEE International Conference on Teaching, Assessment, and Learning for Engineering (TALE), 2018, pp. 134-141. https://doi.org/10.1109/ $\underline{\text { tale.2018.8615422 }}$

[36] M. Kalúz, L. Čirka, and M. Fikar, "Virtual and remote laboratories in education process at FCFT STU," 2011 14th Int. Conf. Interact. Collab. Learn. ICL 2011 - 11th Int. Conf. Virtual Univ. VU'11, no. September, pp. 134-139, 2011. https://doi.org/10.1109/icl.2011.6059562

[37] G. Lückemeyer, "Virtual blended learning enriched by gamification and social aspects in programming education," 10th Int. Conf. Comput. Sci. Educ. ICCSE 2015, no. Iccse, pp. 438-444, 2015. https://doi.org/10.1109/iccse.2015.7250286

[38] E. S. S. Aziz, Y. Chang, S. K. Esche, and C. Chassapis, "A multi-user virtual laboratory environment for gear train design," Comput. Appl. Eng. Educ., vol. 22, no. 4, pp. 788-802, 2014. https://doi.org/10.1002/cae.21573

[39] F.-A. Haase, "'The State of the Art' as an Example for a Textual Linguistic 'Globalization Effect'. Code Switching, Borrowing, and Change of Meaning as Conditions of Cross-Cultural Communication,” Let. Magna Rev. Eletrônica Divulg. Científica em Língua Port. Lingüística e Lit., vol. 13, p. (1-12), 2010. Available: https://www.academia.edu/3042284/ THE_STATE_OF_THE_ART_AS_AN_EXAMPLE_FOR_A_TEXTUAL_LINGUISTIC _GLOBALIZATION_EFFECT._Code_Switching_Borrowing_and_Change_of_Meaning as_Conditions_of_Cross_cultural_Communication [Accessed July, 2019]. https://doi.org/ $\underline{10.1057 / 9780230391147.0018}$

[40] E. I. Neaga and M. Henshaw, "A stakeholder-based analysis of the benefits of network enabled capability,” Def. Secur. Anal., vol. 27, no. 2, pp. 119-134, 2011.https://doi.org/ $\underline{10.1080 / 14751798.2011 .578716}$ 
[41] T. M. Connolly, E. A. Boyle, E. MacArthur, T. Hainey, and J. M. Boyle, "A systematic literature review of empirical evidence on computer games and serious games," Comput. Educ., vol. 59, no. 2, pp. 661-686, 2012. https://doi.org/10.1016/j.compedu.2012.03.004

[42] C. Salzmann and D. Gillet, "From online experiments to smart devices," REV 2008 Remote Eng. Virtual Instrum., pp. 1-5, 2008.

[43] N. Jazdi, "Cyber physical systems in the context of Industry 4.0," 2014 IEEE Autom. Qual. Testing, Robot., pp. 2-4, 2014. https://doi.org/10.1109/AQTR.2014.6857843

\section{Authors}

Giovanni Romagnoli was born in November 1982 in Scandiano (RE), Italy, the town where he still lives with his family. He is a father-of-three. He received his Master Degree (with honours) in Mechanical Engineering for the Food Industry at the University of Parma, Italy. Since 2013, Giovanni Romagnoli is employed as Research Fellow at the Department of Engineering and Architecture of the University of Parma. Since December 2018, he acts as a local manager on the project DigiLab4U (http://digilab4u.com/), he has then become local scientific coordinator of the same project on December 2019. His research interests include virtual and remote lab network initiatives, RFID and supply chain management, production planning \& control systems, improvements and applications of lean manufacturing, and led to the realization of more than 30 works published on International Journals or presented at International Conferences. He is member of the editorial board of the International Journal of Industrial Engineering Computations, and he's listed in the scientific committee of two International Conferences. Some of his work have been awarded with international prizes by the scientific community. He acts as a referee for some International Journals, and he is also an active volunteer in two not-for-profit charities. His ORCID iD is: https://orcid.org/0000-0002-9891-0314

Giovanni Esposito is a $\mathrm{PhD}$ student in Industrial Engineering at the University of Parma (Italy). His research interests comprehend RFID application for supply chain management and supply chain modelling towards Industry 4.0. He also visited the Stuttgart University of Applied Sciences (Germany), and he acts as local manager for the University of Parma on the DigiLab4U project (http://digilab4u.com/). His ORCID iD is https://orcid.org/0000-0001-5150-0855

Antonio Rizzi is a full professor of Logistics and Supply Chain Management at the Department of Engineering and Architecture of the University of Parma. His main research interests are Logistics, Supply Chain Management and retail. In the last 10 years, his research has been focusing on the application of auto-ID and data sharing technologies for supply chain management \& retailing, such as RFID and IoT, the Internet of things. He's the founder and the director of the RFID Lab at the University of Parma, a world leading research centre devised to promote research, training and services to stakeholders, such as technology providers and end users. The centre pioneered research in the Italian RFID arena and has been widely recognized as a worldwide centre of excellence. He co-founded and currently serves as Editor-in-Chief of the International Journal of RF technologies: Research and Applications, edited by IOS press. In the last 15 years, Antonio has been invited to almost one hundred conferences to share 
his research results. He has published over 60 research papers in qualified international journals, that were cited more than 1.500 times. His h-index is 16 . Some of his works have been awarded international prizes by the scientific community.

Francesco Zammori graduated with distinction in 2004 in Management Engineering and completed his post-graduate studies in 2009, when he received a Ph.D. in Industrial Engineering from the University of Pisa. From 2012 he is Assistant Professor at the University of Parma where he teaches Management Accounting Systems, Project Management, Information Science, Data Bases and Information Systems. His research interests mainly concern: (i) Lean Thinking, (ii) Hybrid Production Planning and Control Systems, (iii) Modeling and Simulation (v) Machine Learning and (iv) Project Management. His research activities led to the publication of more than 40 works, most of which accepted on prestigious International Journals.

Massimo Bertolini graduated in mechanical engineering at the University of Parma in 1999, and he achieved a Ph.D. in "Production Systems and Industrial Plants" in 2004 at the same University.

From 2002 to 2014 he was a university researcher in Industrial System Engineering at the University of Parma and from 2014 to 2019 he was Associate Professor. Since December 2019 he has been Full Professor at the "Enzo Ferrari" Engineering Department of the University of Modena and Reggio Emilia. From 2016 to 2019 he was Director of the Centre "Future Technology Lab" of the University of Parma: a research centre on issues related to the development of Industry4.0 applications for logistics and manufacturing processes. His teaching activity has involved the teaching of Industrial Systems and Logistics, Project Management, Lean Production, Simulation of Logistics and Production Systems and Operation Management. He acted as local scientific coordinator for the University of Parma of the project DigiLab4U (http://digilab4u.com/) up to November 2019. From 2013 to 2016 he directed the local unit of Parma in the FP7 project SERAMIS (https://cordis.europa.eu/project/rcn/189040/it).

His research activity produced over 60 papers indexed in Scopus (plus 30 non-Scopus indexed ones). The main topics of the research concern (i) development and testing of artificial intelligence algorithms for the optimization of logistic/production processes; (ii) development and validation of systems for the automation of logistic / production processes through the use of Auto Id technologies (such as RFID); (iii) process optimization through lean management principles (iv) project management and (v) supply chain management.

Dieter Uckelmann studied Mechanical Engineering at TU Braunschweig and received his doctorate at the University of Bremen in the Faculty of Production Engineering. Between 2005 and 2012 he has established and managed the LogDynamics Lab at the University of Bremen. Since 2012 he is a professor for Information Logistics at Hochschule für Technik (HFT) Stuttgart. Additionally, since 2017 he is a visiting professor at the University of Parma, where he co-supervises two PhD candidates. He has been a visiting researcher at the University of Cambridge (UK, 2009) and University of Parma (Italy, 2016). The focus of his research work is in the field of the Internet of Things, Industry 4.0 and Smart Buildings, the value of information, as well as on labbased research and education. Since 2018, he coordinates the project DigiLab4U and works in other research projects on Smart Public Buildings and industrial sensor / 
augmented reality applications. Furthermore, he is co-editor of the "International Journal of RF-Technologies: Research and Applications". Prior to his academic career, he has been working in different management positions for several IT companies.

Article submitted 2019-10-17. Resubmitted 2020-02-06. Final acceptance 2020-02-02. Final version published as submitted by the authors. 


\section{Appendix A - Lab network initiatives (LNIs)}

In this Appendix A we provide an application of the proposed structure to three LNIs, i.e. Go-Lab, LiLa and WebLab-Deusto, as we mentioned in section 4.

Table 3. Information on three LNI collected with the proposed structure.

\begin{tabular}{|c|c|c|c|c|c|c|}
\hline D & KA & ID & Item & Go-Lab solution & LiLa solution & WebLab solution \\
\hline \multirow{10}{*}{ שט } & 1 & 1 & Project full name & \begin{tabular}{|l|} 
Global Online \\
Science Labs for \\
Inquiry Learning \\
in Schools
\end{tabular} & Library of Labs & WebLab-Deusto \\
\hline & 2 & 2 & $\begin{array}{l}\text { Coordinating or- } \\
\text { ganization }\end{array}$ & $\begin{array}{l}\text { University of } \\
\text { Twente, Nether- } \\
\text { lands }\end{array}$ & $\begin{array}{l}\text { Universität Stuttgart, } \\
\text { Germany }\end{array}$ & $\begin{array}{l}\text { University of Deusto, and } \\
\text { DeustoTech - Deusto Insti- } \\
\text { tute of Technology, Spain }\end{array}$ \\
\hline & 3 & 3 & $\begin{array}{l}\text { Partners of the pro- } \\
\text { ject }\end{array}$ & $\begin{array}{l}\text { Fourteen Euro- } \\
\text { pean Universities } \\
1\end{array}$ & $\begin{array}{l}\text { Eight European Uni- } \\
\text { versities } 4\end{array}$ & $\begin{array}{l}\text { Depending on the dissemi- } \\
\text { nated laboratory }{ }^{6}\end{array}$ \\
\hline & 4 & 4 & $\begin{array}{l}\text { Other organiza- } \\
\text { tions/institutions }\end{array}$ & Five partners ${ }^{2}$ & Three partners ${ }^{5}$ & $\begin{array}{l}\text { Depending on the dissemi- } \\
\text { nated laboratory }{ }^{7}\end{array}$ \\
\hline & 5 & 5 & $\begin{array}{l}\text { Sponsor / funding } \\
\text { organization }\end{array}$ & $\begin{array}{l}\text { European Com- } \\
\text { mission, EU's 7th } \\
\text { framework Pro- } \\
\text { gramme }\end{array}$ & $\begin{array}{l}\text { European Commis- } \\
\text { sion in the context of } \\
\text { the eContentplus pro- } \\
\text { gramme }\end{array}$ & $\begin{array}{l}\text { Depending on the dissemi- } \\
\text { nated laboratory }{ }^{8}\end{array}$ \\
\hline & 6 & 6 & $\begin{array}{l}\text { Related papers } \\
\text { (doi) }\end{array}$ & \begin{tabular}{|l|}
$10.1007 / 978-3-$ \\
$642-41175-5 \_25$ \\
$10.1186 / s 40561-$ \\
$014-0003-6$
\end{tabular} & $\begin{array}{l}\text { 10.1109/ISM.2011.96 } \\
\text { 10.1007/978-3-642- } \\
16208-4 \_27\end{array}$ & $\begin{array}{l}\text { 10.1109/ISIE.2006.296127 } \\
\text { 10.3991/ijoe. v8iS1.1952 }\end{array}$ \\
\hline & 7 & 7 & $\begin{array}{l}\text { Project starting } \\
\text { year }\end{array}$ & 2012 & 2009 & 2000 \\
\hline & 8 & 8 & $\begin{array}{l}\text { Project finishing } \\
\text { year }\end{array}$ & 2016 & 2011 & On going \\
\hline & 9 & 9 & Active & $\mathrm{Y}$ & $Y$ & $\mathrm{Y}$ \\
\hline & 10 & 10 & $\begin{array}{l}\text { Abstract of the pro- } \\
\text { ject }\end{array}$ & $\begin{array}{l}\text { https://support.go- } \\
\text { labz.eu/about }\end{array}$ & $\begin{array}{l}\text { https://www.lila-pro- } \\
\text { ject.org/home.html }\end{array}$ & $\begin{array}{l}\text { https://web- } \\
\text { lab.deusto.es/web- } \\
\text { site/about.html }\end{array}$ \\
\hline \multirow{4}{*}{ ט } & 11 & 11 & Network of labs & $\mathrm{Y}$ & $\mathrm{Y}$ & $\mathrm{Y}$ \\
\hline & 12 & 12 & $\begin{array}{l}\text { If networked: how } \\
\text { many labs? }\end{array}$ & $\begin{array}{l}\text { Project started } \\
\text { with } 30 \text { labs, ac- } \\
\text { cordingly to } \\
\text { source } \\
10.1186 / \text { s40561- } \\
014-0003-6 . \text { To } \\
\text { date }(17 / 10 / 2019) \\
\text { there are more } \\
\text { than } 500 \text { labs }\end{array}$ & 9 & 8 \\
\hline & 13 & 13 & $\begin{array}{l}\text { Research / teaching } \\
\text { fields }\end{array}$ & STEM & $\begin{array}{l}\text { Engineering, Com- } \\
\text { puter sciences, } \\
\text { Chemistry, Mathe- } \\
\text { matics, Physics }\end{array}$ & $\begin{array}{l}\text { Programming, Robotics, } \\
\text { Physics, Electrical Engi- } \\
\text { neering, }\end{array}$ \\
\hline & 14 & 14 & Users & $\begin{array}{l}\text { P - Primary } \\
\text { school }(<14 y) ; \mathrm{H}- \\
\text { high school }(14- \\
18)\end{array}$ & $\mathrm{U} ; \mathrm{C} ; \mathrm{R} ; \mathrm{O}$ & $\mathrm{H} ; \mathrm{U} ; \mathrm{R}$ \\
\hline
\end{tabular}




\begin{tabular}{|c|c|c|c|c|c|c|}
\hline & 15 & 15 & $\begin{array}{l}\text { Publicly available } \\
\text { outside project } \\
\text { partners }\end{array}$ & $\begin{array}{l}\text { Yes, the network } \\
\text { is freely accessi- } \\
\text { ble for external } \\
\text { users }\end{array}$ & $\mathrm{Y}$ & Y \\
\hline & 16 & 16 & $\begin{array}{l}\text { Experimentations } \\
\text { in TE } \\
\text { (\#TOTAL:\#remote) }\end{array}$ & $\begin{array}{l}\text { Engineering } \\
(28: 22) \\
\text { Maths }(64: 4) \\
\text { Physics }(355: 38) \\
\text { Technologies } \\
(35: 22)\end{array}$ & - & $\begin{array}{l}\text { Environmental Studies, Me- } \\
\text { chanical Engineering, Elec- } \\
\text { trical Engineering }\end{array}$ \\
\hline & \multirow{5}{*}{17} & 17 & $\begin{array}{l}\text { Types of laborato- } \\
\text { ries (and \# per } \\
\text { types) }\end{array}$ & $\begin{array}{l}\text { Remote and Vir- } \\
\text { tual Labs, and } \\
\text { Data Set Inspec- } \\
\text { tion }\end{array}$ & $\begin{array}{l}\text { Virtual Labs \& Re- } \\
\text { mote experiments }\end{array}$ & Remote and Virtual Labs \\
\hline & & 17.1 & virtual (\#) & $\begin{array}{l}511+17 \text { (data in- } \\
\text { spection) }\end{array}$ & 2 & 1 \\
\hline & & 17.2 & remote (\#) & 54 & 9 & 6 \\
\hline & & 17.3 & hybrid (\#) & $\begin{array}{l}\text { information not } \\
\text { retrieved at the } \\
\text { time of publica- } \\
\text { tion }^{3}\end{array}$ & - & - \\
\hline & & 17.4 & gaming (\#) & $\begin{array}{l}\text { information not } \\
\text { retrieved at the } \\
\text { time of publica- } \\
\text { tion }^{3}\end{array}$ & - & 1 \\
\hline \multirow{9}{*}{ 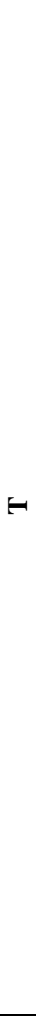 } & 18 & 18 & $\begin{array}{l}\text { Number of layers } \\
\text { of the lab architec- } \\
\text { ture (\#) }\end{array}$ & 4 & 4 & - \\
\hline & 19 & 19 & $\begin{array}{l}\text { Full list of layers' } \\
\text { names }\end{array}$ & $\begin{array}{l}\text { Go-Lap Portal Ar- } \\
\text { chitecture }\end{array}$ & - & - \\
\hline & \multirow{7}{*}{ 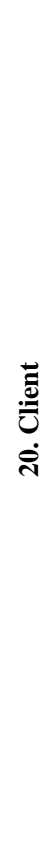 } & 20 & Client layer & $\begin{array}{l}\text { Relatively to the } \\
\text { ILS platform } \\
\text { (some Labs have } \\
\text { direct access) }\end{array}$ & LMS & Core server \\
\hline & & 20.1 & $\begin{array}{l}\text { Main functionali- } \\
\text { ties of the client } \\
\text { layer }\end{array}$ & $\begin{array}{l}\text { Identifies and pro- } \\
\text { files the user giv- } \\
\text { ing different ac- } \\
\text { cess levels }\end{array}$ & $\begin{array}{l}\text { Identifies and profiles } \\
\text { the user giving differ- } \\
\text { ent access levels }\end{array}$ & $\begin{array}{l}\text { Manages authentication, au- } \\
\text { thorization, user tracking, } \\
\text { federation (sharing) and } \\
\text { scheduling }\end{array}$ \\
\hline & & 20.2 & $\begin{array}{l}\text { Kind of connection } \\
\text { with the Learning } \\
\text { Platform (LP) or } \\
\text { with the Lab Server }\end{array}$ & $\begin{array}{l}\text { information not } \\
\text { retrieved at the } \\
\text { time of publica- } \\
\text { tion }^{3}\end{array}$ & SCORM & - \\
\hline & & 20.3 & $\begin{array}{l}\text { Number of differ- } \\
\text { ent users/access } \\
\text { levels }\end{array}$ & 3 & 3 & 3 \\
\hline & & 20.4 & Higher access level & Lab Owner & Admin (Content) & - \\
\hline & & 20.4 .1 & Role \#1 & $\begin{array}{l}\text { Operating and } \\
\text { Publishing } \\
\text { Lab/Publishing } \\
\text { ILS for the Lab }\end{array}$ & $\begin{array}{l}\text { Keeps the understand } \\
\text { the content to include } \\
\text { remote experiments } \\
\text { and virtual laborato- } \\
\text { ries - and not only to } \\
\text { consist of static docu- } \\
\text { ments }\end{array}$ & 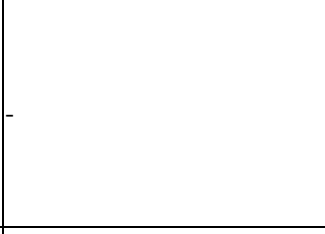 \\
\hline & & 20.4 .2 & Role \#2 & - & $\begin{array}{l}\text { Booking and reserva- } \\
\text { tion time slots }\end{array}$ & - \\
\hline
\end{tabular}




\begin{tabular}{|c|c|c|c|c|c|c|}
\hline & & 20.4 .3 & Role \#3 & - & $\begin{array}{l}\text { Remotely supervise } \\
\text { experiments }\end{array}$ & - \\
\hline & & 20.5 & $\begin{array}{l}\text { Intermediate access } \\
\text { level }\end{array}$ & Teachers & Teachers & Lab server \\
\hline & & 20.5 .1 & Role \#1 & $\begin{array}{l}\text { Design, publish- } \\
\text { ing, and running } \\
\text { ILS and pedagogi- } \\
\text { cal scenario }\end{array}$ & $\begin{array}{l}\text { Remotely control ex- } \\
\text { periments }\end{array}$ & Links user with experiment \\
\hline & & 20.5 .2 & Role \#2 & - & $\begin{array}{l}\text { Checks with the } \\
\text { booking system data- } \\
\text { base whether the cor- } \\
\text { responding user holds } \\
\text { a valid reservation. }\end{array}$ & - \\
\hline & & 20.5 .3 & Role \#3 & 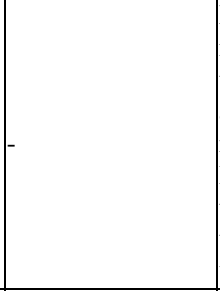 & $\begin{array}{l}\text { Integrates experi- } \\
\text { ments and documents } \\
\text { to interactive courses } \\
\text { and implements an } \\
\text { interactive and intel- } \\
\text { ligent course system } \\
\text { that guides students } \\
\text { through an - real or } \\
\text { virtual - experiment }\end{array}$ & - \\
\hline & & 20.6 & Lower access level & $\begin{array}{l}\text { Students (just for } \\
\text { ILS) via nickname }\end{array}$ & Students & Students \\
\hline & & 20.6 .1 & Role \#1 & $\begin{array}{l}\text { Use of pedagogi- } \\
\text { cal scenario/con- } \\
\text { ducting the exper- } \\
\text { iment }\end{array}$ & $\begin{array}{l}\text { Use of pedagogical } \\
\text { scenario/conducting } \\
\text { the experiment }\end{array}$ & - \\
\hline & & 20.6 .2 & $\begin{array}{l}\text { Are group works } \\
\text { supported? }(\mathrm{Y} / \mathrm{N})\end{array}$ & $\mathrm{Y}$ & $\mathrm{Y}$ & - \\
\hline & & 20.6 .3 & $\begin{array}{l}\text { If so, list possible } \\
\text { roles inside a group }\end{array}$ & $\begin{array}{l}\text { Performing spe- } \\
\text { cific part of the } \\
\text { experiment/Anal- } \\
\text { ysis of results }\end{array}$ & - & - \\
\hline & & 21.1 & Which LP, if any? & Graasp & - & Moodle, Sakai, LMS \\
\hline & & 21.2 & $\begin{array}{l}\text { Kind of connection } \\
\text { with the Lab Server }\end{array}$ & $\begin{array}{l}\text { Standard SAML } \\
\text { (e.g. Shibboleth) }\end{array}$ & - & - \\
\hline & & 21.3 & $\begin{array}{l}\text { Provided Function- } \\
\text { alities }\end{array}$ & & & \\
\hline & $\Xi$ & 21.3 .1 & $\begin{array}{l}\text { Access manager } \\
(\mathrm{Y} / \mathrm{N})\end{array}$ & $\mathrm{Y}$ & Y & Y \\
\hline & $\frac{E}{\vec{E}}$ & 21.3 .2 & $\begin{array}{l}\text { Course selection } \\
(\mathrm{Y} / \mathrm{N})\end{array}$ & $\mathrm{Y}$ & $\mathrm{Y}$ & - \\
\hline$E$ & 恶 & 21.3 .3 & $\begin{array}{l}\text { Pedagogical sce- } \\
\text { nario }(\mathrm{Y} / \mathrm{N})\end{array}$ & $\mathrm{N}$ & $\mathrm{Y}$ & - \\
\hline & בें & 21.3.4 & $\begin{array}{l}\text { Learning analytics } \\
(\mathrm{Y} / \mathrm{N})\end{array}$ & $\mathrm{Y}$ & $\mathrm{Y}$ & - \\
\hline & & 21.3 .5 & $\begin{array}{l}\text { Learner record } \\
\text { store (Y/N, } \\
\text { metadata format) }\end{array}$ & $\begin{array}{l}\text { Y (smart-devices } \\
\text { paradigm based) }\end{array}$ & Y & $\mathrm{Y}$ \\
\hline & & 21.3 .6 & Other & $\begin{array}{l}\text { Integrated Lab } \\
\text { Repository via } \\
\text { GUI to Drupal }\end{array}$ & - & - \\
\hline H & ป் & 22.1 & $\begin{array}{l}\text { Details on web ap- } \\
\text { plication }\end{array}$ & $\begin{array}{l}\text { widgets/apps in } \\
\text { HTML5 }\end{array}$ & - & widgets \\
\hline
\end{tabular}




\begin{tabular}{|c|c|c|c|c|c|c|}
\hline & & 22.2 & $\begin{array}{l}\text { Access manager } \\
(\mathrm{Y} / \mathrm{N})\end{array}$ & $\begin{array}{l}\text { information not } \\
\text { retrieved at the } \\
\text { time of publica- } \\
\text { tion }^{3}\end{array}$ & $\mathrm{Y}$ & $\mathrm{Y}$ \\
\hline & & 22.3 & $\begin{array}{l}\text { Lab scheduler } \\
(\mathrm{Y} / \mathrm{N})\end{array}$ & Y & $\mathrm{Y}$ & Y \\
\hline & & 22.4 & $\begin{array}{l}\text { Kind Graphical } \\
\text { User Interface }\end{array}$ & Adaptive & $2 \mathrm{D}$ & 2D / Adaptive \\
\hline & & 22.5 & $\begin{array}{l}\text { Assisted Experi- } \\
\text { ence/Tutoring } \\
(\mathrm{Y} / \mathrm{N})\end{array}$ & Y & $\mathrm{Y}$ & $\mathrm{Y}$ \\
\hline & & 22.6 & $\begin{array}{l}\text { Single / multi ac- } \\
\text { cess (concurrent) }\end{array}$ & $\begin{array}{l}\text { information not } \\
\text { retrieved at the } \\
\text { time of publica- } \\
\text { tion }^{3}\end{array}$ & Multi access & Concurrent \\
\hline & & 22.7 & Type of experiment & & & \\
\hline & & 22.7 .1 & Repository (Y/N) & $\begin{array}{l}\text { information not } \\
\text { retrieved at the } \\
\text { time of publica- } \\
\text { tion }^{3}\end{array}$ & $\mathrm{Y}$ & $\mathrm{Y}$ \\
\hline & & 22.7 .2 & $\begin{array}{l}\text { Batch Experiments } \\
(\mathrm{Y} / \mathrm{N})\end{array}$ & $\mathrm{Y}$ & $\mathrm{Y}$ & $\mathrm{N}$ \\
\hline & & 22.7 .3 & $\begin{array}{l}\text { Sensor Experi- } \\
\text { ments }(\mathrm{Y} / \mathrm{N})\end{array}$ & Y & $\mathrm{Y}$ & $\mathrm{N}$ \\
\hline & & 22.7 .4 & $\begin{array}{l}\text { Interactive Experi- } \\
\text { ment }(\mathrm{Y} / \mathrm{N})\end{array}$ & $\mathrm{Y}$ & $\mathrm{Y}$ & Y \\
\hline & & 22.8 & Haptics (Y/N) & $\begin{array}{l}\text { information not } \\
\text { retrieved at the } \\
\text { time of publica- } \\
\text { tion }{ }^{3}\end{array}$ & $\mathrm{~N}$ & $\mathrm{~N}$ \\
\hline & & 22.9 & Gamification $(\mathrm{Y} / \mathrm{N})$ & $\begin{array}{l}\text { information not } \\
\text { retrieved at the } \\
\text { time of publica- } \\
\text { tion }^{3}\end{array}$ & $\mathrm{~N}$ & Y \\
\hline & & 23.1 & $\begin{array}{l}\text { If virtual, which } \\
\text { Design Software }\end{array}$ & $\begin{array}{l}\text { App-based lan- } \\
\text { guage (no plug- } \\
\text { ins required) }\end{array}$ & - & - \\
\hline & & 23.2 & If physical: & & & \\
\hline & $\sum^{\underline{\Xi}}$ & 23.2 .1 & $\begin{array}{l}\text { Fully automated } \\
(\mathrm{Y} / \mathrm{N})\end{array}$ & $\begin{array}{l}\text { information not } \\
\text { retrieved at the } \\
\text { time of publica- } \\
\text { tion }^{3}\end{array}$ & Y & $\mathrm{Y}$ \\
\hline E & $\frac{\sum}{\sqrt{5}}$ & 23.2 .2 & $\begin{array}{l}\text { Sensors, Actuator, } \\
\text { and Controller: de- } \\
\text { scription }\end{array}$ & $\begin{array}{l}\text { information not } \\
\text { retrieved at the } \\
\text { time of publica- } \\
\text { tion }^{3}\end{array}$ & - & $\begin{array}{l}\text { ARM microprocessor } \\
\text { called IGEPv2 }\end{array}$ \\
\hline & $\ddot{n}$ & 23.2 .3 & $\begin{array}{l}\text { Smart devices } \\
(\mathrm{Y} / \mathrm{N})\end{array}$ & $\begin{array}{l}\text { information not } \\
\text { retrieved at the } \\
\text { time of publica- } \\
\text { tion }{ }^{3}\end{array}$ & $\mathrm{Y}$ & $\mathrm{Y}$ \\
\hline & & 23.2 .4 & $\begin{array}{l}\text { Smart sensors } \\
(\mathrm{Y} / \mathrm{N})\end{array}$ & $\begin{array}{l}\text { information not } \\
\text { retrieved at the } \\
\text { time of publica- } \\
\text { tion }^{3}\end{array}$ & $\mathrm{Y}$ & $\mathrm{Y}$ \\
\hline
\end{tabular}


${ }^{1}$ Ellinogermaniki Agogi Scholi Panagea Savva AE (Greece), École Polytechnique Fédérale de Lausanne (Switzerland), EUN Partnership AISBL (Belgium), IMC AG (Germany), Reseau Menon E.E.I.G. (Belgium), Universidad Nacional de Educación a Distancia (Spain), University of Leicester (United Kingdom), University of Cyprus (Cyprus), Universität Duisburg-Essen (Germany), Centre for Research and Technology Hellas (Greece), Universidad de la Iglesia de Deusto (Spain), Fachhochschule Kärnten - Gemeinnützige Privatstiftung (Austria), Tartu Ulikool (Estonia). Source: Go-Lab. Deliverable D8.2. Evaluation and validation "dashboard" tool - V1. Source: https://nextlab.golabz.eu/sites/project/files/inline-files/Go-Lab_D8.2-ilovepdf-compressed.pdf. Last access: 09/01/2020

${ }^{2}$ ESA, CERN, NUCLIO, IASA, European Schoolnet. Source: https://nextlab.golabz.eu/sites/project/files/inline-files/Go-Lab_D8.2-ilovepdf-compressed.pdf. Last access: 09/01/2020

${ }^{3}$ This information was not collected at the time of publication, but it could be obtained contacting the lab providers

${ }^{4}$ Technische Universität Berlin (Germany), Technische Universiteit Delft (Netherlands), Linkopings Universitet (Sweden), Universität Basel (Switzerland), Universidad Politecnica de Madrid (Spain), Aristoteleio Panepistimo Thessalonikis (Greece), University of Cambridge (United Kingdom). Source: Library of Labs. Members of the Lila Consortium. Source: https://www.lila-project.org/about/consortium/. Last access: 09/01/2020

${ }^{5}$ Oracle Deutschland (Germany), Computational Modelling Cambridge Ltd. (United Kingdom), MathCore Engineering AB (Sweden). Source: https://www.lila-project.org/about/consortium/. Last access: 09/01/2020

${ }^{6}$ E.g. VISIR laboratory within the VISIR+ project: Instituto Politecnico do Porto IPP (Portugal), Blekinge Institute of Technology BTH (Sweden), Universida Nacional de Educaciçn a Distancia UNED (Spain), Carinthia University of Applied Sciences CUAS (Germany), Universidade Federal de Santa Catarina UFSC (Brazil), Instituto Federal de Santa Catarina IFSC (Brazil), Pontifical Catholic University of Rio de Janeiro PUC (Brazil), Universidad Nacional de Rosario UNR (Argentina), Universidad Nacional de Santiago del Estero UNSE (Argentina).Source: http://www2.isep.ipp.pt/visir/index.php?page=partners. Last access: 09/01/2020

${ }^{7}$ E.g. VISIR laboratory within the VISIR+ project: Associação Brasileira de Educação de Engenharia ABENGE (Brazil), Instituto Rosario de Investigaciones en Ciencias de la Educación IRICE (Argentina). Source: http://www2.isep.ipp.pt/visir/index.php?page=partners. Last access: 09/01/2020

${ }^{8}$ E.g. VISIR laboratory within the VISIR+ project: co-funded by the Erasmus+ Programme of the European Union. Source: http://www2.isep.ipp.pt/visir/. Last access: 09/01/2020

Last access: 09/01/2020 